\title{
A NEW LABOUR ERA FOR SOUTH AFRICAN AIRWAYS
}

\author{
A A Rust \& K Swart, Cape Peninsula University of Technology: Faculty of Business
}

\begin{abstract}
Purpose: In the light of the South African Airways (SAA) (and Heathrow airport) strike in July 2005, an opportunity exists to evaluate the situation in order to address related problems in the future. The role of labour and specifically labour relations in the air travel industry highlights some important factors related to the industry. This paper aims to highlight the specific factors that will address possible reasons for poor workplace relations in SAA. Furthermore, a workable labour relations model for the organisation and other air travel organisations is proposed.
\end{abstract}

In allowing a strike of the magnitude of the SAA strike of 2005 (e.g. a loss of income of R25 million per day), serious labour relations problems in the organisation are obvious. In order to prevent this action, an in-depth study of workplace relations is necessary to focus on the real problems and to adapt and make changes.

Design/Methodology/Approach: This paper is an exploratory exercise based on literature that provides an overview of scholarship in the air travel industry through an analysis of trends and debates, telephonic interviews with role players in the industry and discussions with academics in the tourism industry and in labour relations.

Findings: Taking into account that the air travel industry is technologically advanced, highly labour intensive, very sensitive towards external influences and very competitive, it is therefore important for every employer (including SAA) to design a labour relations system that is fit for the organisation. A suggested labour relations model for SAA is about the ability to build and sustain relationships characterised by shared goals, shared knowledge and mutual respect.

Implications: The effects of strikes and other labour actions in the air travel industry have far reaching impacts on the air travel industry, the tourism industry, as well as the national economy.

Originality/Value: This study highlights the importance of sound labour relations in the industry.

Key words and phrases: Labour relations, air transport industry, South African Airways.

\section{INTRODUCTION}

Although unique, the air travel industry, like many other industries, is in some instances very technologically advanced, and in others highly labour intensive. Sound employer-employee relations or workplace relations is a vital component towards efficiency and ultimately profitability. The employer is always looking for a successful recipe in a relationship that is never complete and in an environment that is sensitive towards external influences and very competitive (Kain \& Webb, 2003:3). Kim (2005:4) and the Centre for Responsive Politics (CRP) (2001:1) contend that air travel has been transformed from a service of the privileged to something more akin to riding trains and buses. Air travel used to be a luxurious way of travelling, but is currently mass transit. Gallagher (2005:3) confirms this fact, indicating that a high growth in demand for variety leads to new routes and planes every year. Oum and Yu (1998:8) add that technological development, increasing globalisation of the world economy, and an increase in personal disposable income are among the factors which have increased demand for air travel worldwide.

The air travel industry is an important contributor to international economic growth and its economic well-being depends on the state of the world economy. In general, the air travel level is closely related to the overall level of economic activity. There is a strong pro-cyclical relationship between the air transport industry and the world economy. That is, air traffic growth generally expands (or contracts) with increased (or reduced) economic growth, but at a much faster rate (Oum \& Yu, 1998:8). The airline industry is a vital part of the world economy. In 1996, the world had approximately 1200 scheduled airlines, of which 300 served international markets. The 255 members of the International Air Transport Association (IATA) in 1996 collectively earned US\$134,3 billion from international scheduled services. It plays a key role in the development of the world economy, tourism, and related activities, by facilitating international trade and economic relations between countries and by stimulating exchange of people and ideas. Countries, regions, cities, markets and businesses are 
often totally dependent on air travel for their success (Abate \& Lelchuk, 2004:1; Manning, 2000:2-3; Oum \& Yu, 1998:5, Poudel, 2003:3 and Ross, 2005:2).

The effectiveness and economic success of the air travel industry depends on its internal organisation and its adaptability towards internal and external influences. In order to be abreast of environmental changes, the air travel industry as well as related industries should be aware of its sensitivity towards external influences. Examples include: the economic recession and Gulf War that caused a decline in air traffic in 1991, the first time in forty years (Oum \& Yu, 1998:199); the terrorist attacks of September 11,2001 , when revenues dropped by nearly $20 \%$ in the months after the attacks and employment levels have also been reduced by nearly $15 \%$ - overall, the industry lost approximately $\$ 8$ billion in 2001 (Gittell, Kochan \& Von Nordenflycht, 2004:25; Gallagher, 2005:3; Gallagher \& Gopwani, 2005:2 and Turnbull, Blyton \& Harvey, 2004:287); the war in Iraq and severe acute respiratory syndrome (SARS) outbreaks in parts of Asia and Canada (Kain \& Webb, 2003:1); heightened security and safety concerns and political uncertainty have caused global tourism to stagnate (Kain \& Webb, 2003:4; Toness, 2005:3 and Bucher, 2005:1); skyrocketing jet fuel prices (Kim, 2005:4); high labour costs (Gallagher, 2005:2 and Oum \& Yu, 1998:42); tough competition (Wolk, 2005:1); weather changes (Lehrer, 2001:5); Internet bookings (CRP, 2001:2); international air transport has been, and still is closely regulated; the existence of agreements has greatly constrained the freedom of individual scheduled airlines; limited competition in the international air transport industry (Oum \& Yu,1998:21); privatisation of government-owned airlines (Oum \& Yu,1998:22); and global sourcing (relocating or off shoring) which has become a trend of moving business to where costs are lowest (Oum \& Yu,1998:42).

Another important contributor to the industry's economic success is the valuation of managementemployee relations. Gittell et al. (2004:3) argue the nature of the relationship to be especially important, given its service-intensive nature, the relatively high ratio of labour costs to total costs, and the high level of union representation in the industry. Since labour costs account for roughly one-third of an airline's costs and unions represent approximately $40 \%$ of the overall air transport industry's employees and over $60 \%$ of the non-managerial employees of the major airlines, employees have the ability to affect airline performance in significant ways (Turnbull et al., 2004:290). Through collective bargaining, employees can achieve higher wages and employment security, leaving orgainsations with higher costs and less operating flexibility. As in other industries, a union wage premium has been well documented in airlines (Turnbull et al., 2004:304). Furthermore, employees can impose additional costs in the process of setting those wages and employment conditions, through strikes or other service disruptions. Thus, employee gains in bargaining power and wages could be seen as necessarily detrimental to both service quality and financial performance. As in other service industries, employees in airlines interact directly with customers, and therefore employees' motivation and satisfaction with their workplace are likely to have important effects on an airline's quality of service and resulting customer satisfaction. Thus, while treating employees as costs to be minimised might be expected to lead to lower service quality and lower productivity, efforts to build a positive workplace culture by encouraging employee participation in problem-solving and teamwork might be expected to lead to higher service quality and higher productivity (Kochan, Von Nordenflycht, McKersie \& Gittell, 2003:3).

In light of the above, it is important that this unique industry, and more specifically South African Airways, with its technologically advanced and labour intensive characteristics, its independency towards effective internal organisation and sensitivity towards external influences, the valuation of management-employee relations towards the industry's economic success, and its important contribution to international economic growth, focuses on the relevant issues in order to become effective, efficient and adopt world class standards.

\section{PROBLEM TO BE INVESTIGATED}

Due to the strike at SAA in 2005, it is assumed that the wage dispute is the highlight of a variety of conflicts that has undertones of many other examples of frustration and unsatisfactory behaviour. A strike is a culmination of, normally, many factors. A strike has a developmental phase with accumulating conflicts, disputes and deadlocks that has an end result of industrial action where employees withhold their labour (Sauer \& Voelker, 1993:224 and Venter, 2003:470). Non-strike actions can be as severe as a strike. 
Non-strike work actions include various forms of slowdowns such as sickouts, work-to-rule, and refusals to work overtime. In order to prevent these actions, an in-depth study of workplace relations is necessary to focus on the real problems and to adapt and make changes. Kochan et al. (2003:2) highlights this problem by saying that labour relations in the airline industry is in general in a crisis. The entire industry is searching for a business model that works in the post September 11, 2001 marketplace.

\section{AIM OF THE STUDY}

This study aims to highlight the specific factors that will address possible reasons for poor workplace relations in SAA. In addition, the study proposes a design of a workable labour relations model for the organisation. The idea is not to avoid unions, but to build an effective labour relations system by focusing on the quality of the relationships among role players (employees, supervisors, managers and customers), and on reaching collective bargaining agreements in a timely and peaceful fashion. Such a model appears to offer considerable potential for improving financial performance and the industry's overall service quality.

\section{METHODOLOGY}

This study is an exploratory exercise based on literature that provides an overview of scholarship in the air travel industry through an analysis of trends and debates. The selection of sources (documents; texts; websites; interviews) is representative through the extensive research done specifically in the USA on labour relations in the air travel industry. This literature study is accepted to be comprehensive and well-integrated with the topic. Other sources of information were telephonic interviews with staff of South African Airways and other organisations in the air travel industry and discussions with academics in the tourism industry and in labour relations. The use of these sources is combined in order to conduct a background study into the SAA strike, to investigate world-class operations, and to recommend a workable model for the organisation.

\section{SAA STRIKE}

The United States General Accounting Office (GAO) (2003:1) underscores that airline strikes, in the past, have had obvious negative impacts on communities, including lost income for striking and laid off workers, disrupted travel plans, fewer travellers and less spending in travel related businesses and decreased spending by travellers and the struck airline. The local economy is significantly affected by a strike. For example, cancelled flights have lead to the layoff of non-striking employees, fewer travellers in the airport spending money in concessions, and reduced landing fees for airports. Because passenger traffic dropped, spending at hotels also suffered (GAO, 2003:16).

The SAA strike in July 2005 also had severe consequences on its market share, profitability and longterm workplace relations. Makings (2005a:1) adds that SAA is expected to report a profit of about R80-million for the year ending March 2006 - a dramatic turnaround from the R244-million loss recorded in 1998. In the previous year, the airline showed a loss of R323-million. The reversal of fortunes can be attributed primarily to a restructuring of top management, the cutting of unprofitable routes, sharply improved customer service, an ongoing fleet upgrade of fuel-efficient aircraft, broadening of international alliances and a $10 \%$ cut in staff. These actions came with a price and left its mark on workplace relations. Makings (2005b:1) refers to this as too much government interference in SAA's management. Phasiwe (2005:1) argues that other reasons could contribute to dissatisfaction: the dismissals of two senior executives (Hamilton-Manns and Acton); and the suspension of about ten other SAA managers on various charges since the CEO's, Khaya Ngqula, anticorruption stance and his crusade to "purge" those who challenged his leadership style. Wadula (2005:1) also questioned the management style of the CEO. Furthermore, Mashalaba (2005:1) identified a poor communication strategy as a major reason for the strike.

The dispute was about a demanded eight percent increase in wages by the two unions involved, SA Transport and Allied Workers Union (Satawu) and United Association of SA (UASA) as opposed to five percent offered by management Mametse (2005:1). Cosatu Weekly (2005:1) elaborates that the long negotiations took place against a backdrop of a massive increase in profits for the airline, and the workers wanted a share of this in their wage packets. During the strike that followed, no international or regional flights had taken off or landed. International and regional flights were cancelled while 
contingency plans, like using competitors to take passengers to their destinations, within the country, were used. The strike, one of the worst in the airline's history, has played havoc with travel schedules across Africa where SAA is the dominant regional carrier (Evans, 2005:1 and The Namibian, 2005:1).

The impact of the strike was severe. The problem was even addressed at the highest level of national affairs when the Minister on Environment Affairs and Tourism had to answer questions in Parliament regarding the SAA strike (National Assembly, 2005:2). ASATA (2005:1) adds that travel management consultants around the country worked long hours during the strike on their behalf, trying to re-route and assist passengers in most cases at no cost to the passenger, but obviously costs were incurred by the agents. Costs involved included that of communication via e-mail, phone calls locally and internationally, and of course loss of time. For the passenger, the costs included the "loss" of accommodation (e.g. attend funerals, have medical appointments or operations), business trips, package tours, car hire and cruises, due to cancellation of flights. The SAA strike had a crippling effect on local tourism, especially with international tourists being forced to cancel or postpone their trips. Local travel agents, however, benefited from it. They assisted numerous stranded passengers in South Africa and abroad. Mametse (2005:1) goes further, and says that while thousands of airline passengers are stranded all over the world because of the SAA strike, loads of undelivered cargo has also been accumulating.

The estimated cost of the strike by economists for SAA was about half of its daily turnover of 50 million rand (\$7.5 million) to be totalled to R200 million (The Namibian, 2005:1 and Business Week, 2005:1). However, other more serious costs to labour relations, was the concern that the handling of the strike had dented the reputation of the airline. The economic effects of the industrial action would be felt in the months to come; such as lost business opportunities, but the relations damage was irreparable. This view is supported by Andrew Levy, labour expert for Andrew Levy \& Associates (in Mashalaba, 2005:1), who said SAA had come out of the action bruised because its image had been damaged and it would take a gigantic effort to bring back lost customers. Although each strike is unique, the circumstances of the organisation should be studied before any judgements can be justifiable and before any advice can be relevant.

\section{UNIQUENESS OF THE AIR TRAVEL INDUSTRY}

The air travel industry is unique in many aspects and all of them impact on the smooth running of its activities. It is an extremely competitive, safety-sensitive, high technology (highly knowledge-based market) service industry (Applebaum \& Fewster, 2003:59).

The nature of workplace relations is important in the airline industry, given its service-intensive nature, and also the relatively high ratio of labour costs to total costs, and the relatively high level of union representation in the industry (Gittell et al., 2004: 3). Employees have the ability to affect airline performance in significant ways (e.g. service disruption and high wage demands) because labour costs account for roughly one-third of an airline's costs and unions represent approximately $40 \%$ of the overall air transport industry's employees and over $60 \%$ of the non-managerial employees of the major airlines (Turnbull et al., 2004:290). Kochan et al. (2003:3) also point out that labour costs are the biggest variable cost in airline operations. Given their magnitude, it is not surprising that labour costs become a focal point when organisations need to reduce costs. Reductions in wages were also associated with reductions in service quality, which in turn led to lower profitability. Thus, while lowering wages clearly provides short-term relief to organisations over the long-term, the effects of wage and other contract changes are determined in part by their effects on productivity and customer service and other aspects of airline operations. These operational performance outcomes were, in turn, heavily influenced by the quality of employee and labour relations, specifically by the culture of day-to-day workplace relationships and the amount of conflict experienced in collective bargaining negotiations. Turnbull et al. (2004:290) highlight specific features of the industry that foster inconsistent HR policies, expose the power relationship between management and labour, and render partnership arrangements extremely problematic:

- The product is extremely perishable and airlines have no real inventory. If flights are cancelled, airlines cannot 'stockpile' or easily recover lost traffic. This factor works against partnerships, because any downturn in business is usually accompanied by capacity cuts that result in job 
losses (often the death-knell for partnership). Downsizing often destroys the foundation of trust and cooperation between management and labour.

- The pro-cyclical pattern of demand for air transport services. In general, traffic expands with increased economic growth, and vice versa, but at a much faster rate. For example, during any downturn or crisis, costs will be tightly controlled and employees are usually expected to make 'sacrifices' to safeguard the financial position of the airline. When business picks up, airlines remain cautious on costs, knowing that traffic might be lost to rivals in an increasingly competitive and deregulated aviation market.

- Labour accounts for a significant proportion of total operating costs. Moreover, labour costs are one of the few 'variable' costs under the direct and more immediate control of management (unlike fuel costs, landing charges, and aircraft costs).

\section{EFFICIENCYISUCCESS IN THE INDUSTRY}

The striving for success in the air travel industry is mainly about financial profitability that includes a variety of focus areas with different priorities for different participants. Income vs. cost is the bottom line. Labour is involved in operations on the income and cost side, specifically its involvement in productivity (Kochan et al., 2003:3). In practice, it means servicing aircraft, passengers, baggage, and freight in a consistent and reliable way under high-pressure conditions (Gittell, 2003:xiii). Oum and Yu $(1998: 1,42)$ further indicate that international airlines face similar problems as organisations in other globalised industries. It is becoming increasingly exposed to the pressures of the marketplace. Increased competition and recessions led to severe and widespread losses in the international airline industry, forcing many airlines to undertake major restructuring to improve productivity and reduce costs. The ultimate ability of a carrier to survive and prosper in increasingly competitive markets greatly depends on its productivity and cost competitiveness (i.e. if its unit costs are constantly lower than that of competitors). Airline cost differentials are thus determined by differences in input prices and productive efficiency. Input prices are the cost of providing airline services at prices paid per unit of labour, fuel, aircraft and infrastructure services, purchased materials and other services. Labour accounts for about $30 \%$ of an airline's total cost. A clear upward trend exists in average labour prices for all airlines, but there are substantial differences in average labour prices across airlines. An effect of this is global sourcing (relocating or off-shoring). It is a trend of moving business to where costs are lowest and potential productivity gains are the highest. Relocated work includes back office functions, highly repetitive work, and leased cabin crew and pilots.

The following are accepted as key elements for productive efficiency success (Gittell et al., 2004:9 and Oum \& Yu, 1998:11):

- Relational factors. Relational factors (i.e. workplace relations like conflict handling and workplace culture) are more important determinants of performance than the structural factors (i.e. structures for collective bargaining). Sustained improvement in service quality and financial performance require more fundamental improvements in the quality of labour relations.

- Service quality. Service quality is defined as the safety and reliability of the travel experience. Employees can influence service quality in this industry either through their direct interactions with customers or through the indirect impact of their actions on the customer experience (loading or failing to load a bag, adhering to or violating safety procedures, and so on). Reliability is measured negatively as late arrivals (percent of flights arriving more than 15 minutes late); lost bags (number of mishandled bags per thousand passengers); and complaints per million passengers. Gittell (2003:xiii) also points out that services include providing aircraft, passengers, baggage, and freight in a consistent and reliable way under high-pressure conditions.

- Labour productivity. Labour productivity is typically measured as a ratio of output to labour input. Often, airline labour productivity is measured as total revenue passenger miles (RPM) per employee. Turnbull et al. (2004:294) argue that many airline industries outsource activities that can be provided more cheaply by third parties. The outsourced organisations have economies of scale. 
- Aircraft productivity. Aircraft productivity is computed as block hours per aircraft day, where block hours are the hours between pulling back from the airport gate and arrival at the down-line airport gate. These are the hours that an aircraft is considered to be in a revenue-producing mode. While this ratio does not include a measure of input, aircraft utilisation can be strongly affected by the extent to which employees cooperate, coordinate, and exert discretionary effort in getting planes loaded and turned around quickly.

On the selling side, specifically, amongst many other aspects, Makings (2005b:3) suggests a respected brand, a frequent flyer programme, seamless overseas travel, and a reward to passenger loyalty. Oum and Yu (1998:17) further point out the importance of strategic alliances with other airlines. Airlines construct alliances to gain access to global networks within the constraints of the current bilateral air service agreement (ASA) system. Alliances provide for a large service network, better services, and more attractive frequent flyer programs, better access at congested airports, reduced costs through economies of scale associated with joint marketing, maintenance, ground facilities, training, purchasing of aircraft and fuel. The main aim with alliances is to enhance partner airlines' competitive position and to achieve higher profits for each of the partners.

Efficiency and success in the industry are also negatively affected by avoidable products, as presented in the next section. These products should certainly not form part of the daily operations of an air travel organisation.

\section{AVOIDABLE PRODUCTS}

Examples of inefficiency in the industry that are negatively affecting success include: delays (vs ontime), long lines, crowds, lost baggage, overbooked flights, and pricey fares (CRP, 2001:1; GAO, 2003:25; Gittell, 2003:xi and Lehrer, 2001:1). Common factors for delays include severe weather conditions, aircraft maintenance, runway closures, customer service issues (e.g. baggage and accommodating passengers with special needs, such as those in wheelchairs or youths requiring escorts), air traffic control system decisions, and equipment failures. Typical reasons given for these are: mechanical problems, inability to secure crew, weather, or labour unrest. One other significant obstacle in the air travel industry is the deep divisions between workers groups and among the functions involved in air travel. Oum and Yu (1998:114) also point out that majority government ownership is shown to have a significant negative impact on the productive efficiency of an airline.

\section{AIRCRAFT OPERATIONS}

Another unique aspect of the air travel industry is the different specialised groups of workers that are focusing on specific fields. All of them have a role in the aircraft operations in order to allow a craft to depart. Gittell (2003:26) states that the flight departure process is one of the core processes of an airline's operations. Representatives of about twelve functions perform a complex set of tasks between the arrival of the plane and its next departure. It is further complicated by changes in weather, connections, and gate availability. There is tremendous pressure to get a plane out on time. Conflict can be expected in this process where multiple functions happen, particularly when these processes are highly interdependent. Cross-functional conflict is seen as an occasion for learning (focus on learning rather than blaming). Communication in this process is very important between the specific functions. Problem solving communication is necessary. It enables employees to adapt quickly and work together when things go wrong. Blaming is also avoided because blaming each other for negative outcomes is counter-productive.

Identified groups include (CPR, 2001:2; Gallagher, 2005:1; GAO, 2003:5; Kim, 2005:2; Lehrer, 2001:4; Marek, 2005:1 and Turnbull et al., 2004:293): pilots (cockpit), cabin crew, flight attendants (perform on-the-spot maintenance on aircraft at airports and help guide planes in and out of airport gates), mechanics, gate agents, ticket agents, ramp workers, baggage transfer agents, baggage handlers, aircraft cleaners, caterers, fuellers, freight agents, operation agents, air traffic controllers (organise the distance between airplanes and manning ground radars), and travel agents (indirectly responsible for ticket sales; can negotiate better fares). Although terms may differ, the operations at SAA do not differ from other international organisations as illustrated below. 


\section{AIRCRAFT OPERATIONS AT SAA}

The following table provides an overview of aircraft operations at SAA (Dreyer, 2006).

Table 1: SAA operations

\begin{tabular}{|c|c|c|}
\hline No & Group & Function \\
\hline 1 & $\begin{array}{l}\text { Scheduling + Marketing } \\
\text { Department (SAA staff) }\end{array}$ & Looking at financial sustainability of possible routes \\
\hline 2 & $\begin{array}{l}\text { Performance Engineering } \\
\text { Department (SAA staff) }\end{array}$ & $\begin{array}{l}\text { Evaluate physical possibilities, i.e. identify aircraft } \\
\text { fleet and payload for specific routes. (Every } 6 \\
\text { months). }\end{array}$ \\
\hline 3 & $\begin{array}{l}\text { Route Analysis department (SAA } \\
\text { staff) }\end{array}$ & Build optimum routes regarding costs \\
\hline 4 & $\begin{array}{l}\text { Honeywell (a consultancy } \\
\text { company that specialises in } \\
\text { software information and aircraft } \\
\text { hardware) [Outsider] }\end{array}$ & $\begin{array}{l}\text { Forward routes to } 3^{\mathrm{RD}} \text { party for navigation database } \\
\text { of specific fleets }\end{array}$ \\
\hline 5 & $\begin{array}{l}\text { Equity Aviation and Technical } \\
\text { Department [both Outsiders] }\end{array}$ & Aircraft position on apron (check air crafts) \\
\hline 6 & Technical Department [Outsider] & ${ }^{*}$ Technical staff do serviceability checks \\
\hline 7 & $\begin{array}{l}\text { Refuel company and Technical } \\
\text { staff [Outsiders] }\end{array}$ & Refuel of aircraft \\
\hline 8 & Reservations (SAA staff) & Reservations of people \\
\hline 9 & Check in staff (SAA staff) & Check in counters \\
\hline 10 & $\begin{array}{l}\text { Departure control Department } \\
\text { (SAA staff) }\end{array}$ & $\begin{array}{l}\text { Weight and Balance information to crew (important } \\
\text { information to get centre of gravity) }\end{array}$ \\
\hline 11 & Equity Aviation [Outsiders] & $\begin{array}{l}\text { To provide water and support equipment (tugs, tow } \\
\text { bars, stairs, etc.) }\end{array}$ \\
\hline 12 & Vehicle (Tug) [Outsiders] & To push back aircraft, need to be ordered \\
\hline 13 & Catering (Air Chefs) [Outsiders] & To load food and beverages \\
\hline 14 & Cleaning staff (AHS) [Outsiders] & $\begin{array}{l}\text { To prepare aircraft for passengers - make aircraft } \\
\text { sterile }\end{array}$ \\
\hline 15 & Cargo Department (SAA staff) & To get cargo at aircraft \\
\hline 16 & $\begin{array}{l}{ }^{* *} \text { Load masters from Equity, ramp } \\
\text { coordinators verify from SAA } \\
\text { [Outsiders and SAA staff] }\end{array}$ & $\begin{array}{l}\text { Loading of aircraft according to regulations and load } \\
\text { sheet }\end{array}$ \\
\hline 17 & Flying crew (SAA staff) & $\begin{array}{l}\text { Signing on } 2 \text { hours before flight to prepare 'e'-tops, } \\
\text { routes, winds, times, and other external factors }\end{array}$ \\
\hline 18 & Dispatch Department (SAA staff) & Provide flight plans and weather for flight \\
\hline 19 & Cabin crew (SAA staff) & Sign on 2 hours before flight for briefing \\
\hline 20 & $\begin{array}{l}\text { Equity provide transport for crew } \\
\text { [Outsiders] }\end{array}$ & Transport to aircraft for crew \\
\hline 21 & Cabin crew (SAA staff) & Prepare and do safety checks \\
\hline 22 & Cockpit crew (SAA staff) & Check technical status of aircraft and prepare cockpit \\
\hline 23 & Technical Department [Outsiders) & Sign aircraft off serviceable \\
\hline 24 & Load masters [Outsiders] & Sign off correct loading of aircraft. \\
\hline 25 & Cockpit crew (SAA staff) & Requests clearance for push back and take-off \\
\hline
\end{tabular}

*Air crafts are checked and serviced in a hanger on specific schedules: daily checks, through checks, weekly checks, A-checks (every six weeks), C-checks (every 18 months).

**Loadmaster: manages loading on cargo planes; fly with plane and is normally employed by owner of aircraft.

***Loading Supervisor: manages a team of sorters and loaders that loads a plane according to a load plan; employed by company who is responsible for loading (Equity in case of SAA)

${ }^{\star * \star \star}$ Ramp coordinators: manage the whole operation around the aircraft, e.g. fuelling, loading, gives instruction for passengers to move through gates; liaise between cabin crew and ground; are normally employed by the aircraft owner. 


\section{SUGGESTED MODEL}

In order to design a workable and effective labour relations solution for SAA, the variety of the industry and its uniqueness should be taken into account to form the foundation for future operations. Due to the important role employees play as a production factor, and given the power of the trade unions (Satawu and Uasa) involved, much more focus should be given to employee productivity and therefore employee relations. The worker plays a key role in this industry and should therefore receive the necessary credit for that. This is achievable, but not easy, particularly after a strike (Dreyer, 2006 and Gittell, 2003:209). The main aim is to ensure competitiveness (i.e. competitive input prices and production efficiency). Kochan et al. (2003:14) argue that the critical factors that need attention are: development with the aim of improving the workplace culture, employee-management relations, cross-functional/cross-occupational coordination, flexibility, cooperation, and conflict resolution. Gittell (2003:xi) is of the opinion that this is possible if the "secret ingredient" to build and sustain high performance relationships among role players (managers, employees, unions, suppliers) are addressed. These relationships are characterised by shared goals, shared knowledge (awareness of overall work processes) and mutual respect (no status differences; everyone is important; and to count on someone next in the line). It goes with development of organisational practices that build and sustain strong relationships among those who are critical to the organisation's success. The focus is on the quality of relationships and investment in long-term maintenance of relationships among managers, employees and business partners.

This type of relationship helps to support frequent, timely, problem-solving dialogue and allows the provision of high-quality service to passengers. As outlined by Gittell (2003:12), the success factors involved include:

Leadership: Leaders should have credibility. This is the ability to inspire trust and a belief by employees that their leaders care deeply about their well-being. Supervisors, for example, should act as player coaches (having managerial authority but also performing the work of frontline workers). This creates a unique culture (focus on relationships).

Culture: The main focus is on relationships and more so the underlying quality of relationships. This forms a collective identity with others and the organisation. Applebaum and Fewster (2003:61) refer to it as the family-like fabric of an organisation. The aim is to grow customer satisfaction, increase the market share, care about organisational assets, and save lives with high levels of employee satisfaction (Applebaum \& Fewster, 2003:59 and Kim, 2005:2). In addition, to achieve the primary goals of the airline industry, safety, on-time performance, and satisfying the customer are crucial. All employees must have "soft skills" such as customer orientation and teamwork ability to relate effectively with others. The relationships extend beyond the work itself, spilling over into friendships. Management should bridge the work/family divide and recognise and encourage the energy that good family and community relationships bring to the workplace and vice versa. Requirements for effective culture building include:

- Communication: The ILO (2005:1) proposes that the main requirement for sound relationships is ongoing healthy communication. This includes frequent communication, timely communication and problem-solving communication.

- Ownership: Employees in the travel industry should take ownership in decision-making regarding their immediate work life by implementing practices that involve employees in solving operational problems (Applebaum \& Fewster, 2003:59-63; Gittell et al., 2004:5 and Toness, 2005:2). GAO (2003:13) maintains that the quality of labour relationships is defined by the parties' level of trust, their level of communication, and their ability to solve problems. A workplace culture of high trust will allow workers to take control over their tasks. The spin offs include more committed, motivated, responsible workers. It includes credit, recognition and being compensated as important assets in a variety of modes. Shared governance is another option with positive results, but, Gittell et al. (2004:14) cautions, however, that without an accompanying improvement in the underlying relationship between employees and management, shared governance can lead to a worsening of the labour-management relationship because of disappointed expectations. 
- Training and development: Employees should be made aware of the importance of all the internal role players (customers) in the organisation (Applebaum \& Fewster, 2003:60). Internal marketing (have an awareness of and interest in internal customers opinions and insights) strategies are necessary to gain customer lock-on. The organisation should provide enough and sufficient internal services (i.e. training and development) that would contribute to optimising internal customer performance.

- Measuring: Organisations need to manage information properly (Applebaum \& Fewster, 2003:62). Ongoing measuring (e.g. on-time performance, baggage handling and customer complaints) and quick reaction towards results should be done. The organisation should know what their external customers value and how and why employees provide that value. Employee opinion surveys on: organisational culture; leadership; relations; benefits; compensation; and training and development on teamwork, communication skills, socialisation, customer care (internal and external), etc., must be conducted. Audits to ascertain the gaps between what they thought their airlines were doing and what they actually were doing (a reality check) should also be conducted regularly.

- Respectful relationship with the trade union: Respectful relationships between management and trade unions appear to set the tone for respectful relationships throughout the organisation (Gittell, 2003:182). Positive labour/management relations are not achieved once and for all. Rather they have to be reproduced every day. The relationship is never complete. However, Turnbull et al. (2004:289) warns that parties in a collective relationship should always understand that in the Capitalistic economy system, employment relationships exhibit tension and conflict; the employer wants employees to be highly committed and cost-effective as well as dependable and yet disposable; and that the employer has normally greater power resources than employees.

Strategy: This is about quick turnaround of aircraft, while doing it safely and accurately based on leanness, speed and reliability. It refers to minimising the time aircraft spend on the ground (nonrevenue producing time). When a plane spends less time on the ground, it is able to earn more revenue per day. This requires highly effective working relationships among all parties involved and intense focus on teamwork. Specific functions to be completed include unloading the plane, servicing, and reloading. Coordination forms the primary role. One bad apple - or inconsistent practice - can spoil the whole bunch.

Coordination: One of the core processes in the provision of air travel is the flight departure process. This requires a high degree of coordination under time constraints for a successful completion. It further requires intense focus, commitment and passion for shared goals, knowledge and mutual respect, and frequent, timely, problem-solving communication. These practices must be synchronised and harmonised.

The above requires an in-depth audit into the managerial operations of SAA. An audit will highlight the existing practices as well as shortcomings. Thereafter, management should design a strategy in order to address the shortcomings. This in itself is an intensive process and requires brave managers and a culture change.

\section{CONCLUSION}

The SAA strike of 2005 cost the airline about R200 million, an indication of high volumes of money lost in a short period. This highlights the importance of sound labour relations in the industry. Employers in the air travel industry are always looking for a successful recipe in workplace relations, because it is a vital component towards efficiency and ultimately profitability. Taking into account that the industry is very technologically advanced, highly labour intensive, very sensitive towards external influences and very competitive, it is therefore important for every employer (including SAA) to design a labour relations system that is suitable for the organisation. Management-employee relations are specifically important to economic success. The reason is its service-intensive nature, the relatively high ratio of labour costs to total costs, and the high level of union representation in the industry.

A suggested labour relations model for SAA revolves around the ability to build and sustain relationships characterised by shared goals, shared knowledge and mutual respect (Gittell, 2003:12). 
The success factors involved in the creation of the model, include: credible leadership; a culture of quality relationships (based on ongoing healthy communication, i.e. frequent communication, timely communication and problem-solving communication); employees that take ownership in decisionmaking regarding their immediate work life; training and development (for example, employees should be made aware of the importance of all the internal role players (customers) in the organisation); ongoing measuring about what their external customers value and how and why employees provide that value; respectful relationships with the trade unions that needs daily attention; a strategy that is about quick turnaround of aircraft and which includes highly effective working relationships among all parties involved and intense focus on teamwork; and coordination, specifically with the flight departure process. This requires a high degree of coordination under time constraints for a successful completion. It further requires intense focus, commitment and passion for shared goals, knowledge and mutual respect, and frequent, timely, problem-solving communication.

\section{REFERENCES}

Abate T \& Lelchuk I. 2004. Strike raises concerns about tourism. Labor leaders say they limited SF walkout to spare industry, 30 September [Online] Available from: www.sfgate.com/cgi-in/article.cgi?file=/ chronicle/archive/2004/09/30/BUG61912QI1.DTL\&type=business $-31 \mathrm{k}$

[Accessed: 09/09/2005]

Applebaum SH \& Fewster M. 2003. Global aviation human resource management: contemporary compensation and benefits practices. Management research news. 26(7):59-71.

ASATA (Association of South African Travel Agents). 2005. No end to costly SAA strike, 27 July [Online] Available from: www.asata.co.za/pages_archives/news_050900.htm - 61k - [Accessed: 09/09/2005].

Bucher N. 2005. The air traffic controllers' strike of 1981 [Online] Available from: www.stfrancis.edu/ba/ghkickul/ stuwebs/btopics/works/atcstrike.htm - 17k -[Accessed: 09/09/2005].

Business Week (Mmegi). 2005, Mediator sees progress on SAA strike, 28 July [Online] Available from: http://www.mmegi.bw/2005/July/Thursday28/68621049293.html [Accessed: 04/10/2005].

Cosatu Weekly. 2005. SAA strike takes off [Online] Available from: http://www.cosatu.org.za/news/weekly/20050722.htm [Accessed: 04/10/2005].

CRP (Centre for Responsive Politics). 2001. Airline passenger Bill of Rights, 26 Febryuary [Online] Available from: www.opensecrets.org/news/airlines/ - 17k - [Accessed: 09/09/2005].

Dreyer F. 2006. Interview with Manager, Flight Technical Liaison \& Deputy Post Holder, Maintenance, Johannesburg International Airways Park, Kempton Park on 30 March, Cape Town.

Evans J. 2005. Agreement drafted to resolve SAA strike, Mail \& Guardian online, 27 July [Online] Available from:

http://www.mg.co.za/articlePage.aspx?articleid=246528\&area=/breaking_news/breaking_news_busi ness/ [Accessed: 04/10/2005].

Gallagher J. 2005. Northwest's strike toll: 1200 jobs gone, 23 August [Online] Available from: www.freep.com/money/business/nwa-bar123e_20050823.htm - 46k [Accessed: 09/09/2005].

Gallagher J \& Gopwani J. 2005. Mechanics walk out, 20 August [Online] Available from: www.freep.com/money/business/nwa20e_20050820.htm - 47k- [Accessed: 09/09/2005].

GAO (United States General Accounting Office). 2003. Airline labor relations: Information on trends and impact of labor actions, U.S. Senate, GAO-03-652, June.

Gittel JH, Kochan TA \& Von Nordenflycht A. 2004. Mutual gains or zero sum? Labor relations and firm performance in the airline industry. Industrial and Labor Relations Review, 57(2).

Gittell JH. 2003. The Southwest airline way. New York: McGraw-Hill. 
ILO. 2005. Declaration on Fundamental Principles and Rights at work - Cambodia: Labour dispute resolution [Online] Available from:

www.ilo.org/dyn/declaris/DECLARATIONWEB. ProjectDetails?var_Language=EN\&var_ID=204 - 28k 12 Oct 2005 - [Accessed: 09/09/2005].

Kain J \& Webb R. 2003. Turbulent Times: Australian Airline Industry Issues, Economics, Commerce and Industrial Relations Group, Department of the Parliamentary Library, Research Paper, No. 10 2002-03.

Kim T. 2005. What a Northwest strike might mean, August 18 [Online] Available from: www.indystar.com/apps/pbcs.dll/article?AID=/20050818/BUSINESS/508180516/0/NEWS01 - 60k Supplemental Result -[Accessed: 09/09/2005].

Kochan T, Von Nordenflycht A, McKersie R \& Gittell JH. 2003. Out of the ashes: Options for rebuilding airline labor relations, MIT Sloan School of Management, Working Paper 4301-03, Institute for Work and Employment Research (IWER), Working Paper 04-2003, March.

Lehrer J. 2001. Secretary of Transportation Norman Mineta talks about the troubled airline industry [Online] Available from: 12 April, www.pbs.org/newshour/bb/transportation/ jan-june01/mineta_512.html - 38k - [Accessed: 09/09/2005].

Makings R. 2005a. SA Airways in R324m turnaround [Online] Available from: http://www.C:IdatalMy documents|My documents|Research/Air strikesISA Airways in R324m turnaroun.htm [Accessed: 18/10/2005].

Makings R. 2005b. Private airlines soaring as SAA labours under official hands, Business Times [Online] Available from: http://www.C:IdatalMy documentsIMy documents|ResearchIAir strikesIPrivate airlines soaring as SAA labours under official hands.htm [Accessed:18/10/2005].

Mametse D. 2005. Cargo also stranded, Moneweb [Online] Available from: http://www.C:IdatalMy documentsIMy documentsIResearchlAir strikesIMoneyweb.htm [Accessed: 04/10/2005].

Manning J. 2000. The air traffic controllers' strike [Online] Available from: http://www.eightiesclub.tripod.com/id296.htm - 18k - [Accessed: 09/09/2005].

Marek L. 2005. Northwest shares rise as flights operate amid delays, August [Online] Available from: www. bloomberg.com/apps/news?pid=10000103\& refer=\&sid=aVi2LG .oayjY - 58k - Supplemental Result -[Accessed: 09/09/2005].

Mashalaba S. 2005. SAA will take flight after being grounded by strike, City Press Business, 30 July [Online] Available from: http://www.news24.com/City_Press/Finance/0,,186-246_1746476,00.html [Accessed: 09/09/2005].

National Assembly. 2005. Hansard Papers, Question no. 111, Internal question paper no. 25 of 2005, Date of publication: 18 August 2005.

Oum TH \& Yu C. 1998. Winning airlines: Productivity and cost competitiveness of the world's major airlines. Norwell : Kluwer Academic Distributors.

Phasiwe K. 2005. Tender row sees another top SAA exec quit, Business Day [Online] Available from: http://www.C:IdatalMy documentsIMy documents|ResearchlAirstrikeslallAfrica_com [Accessed:18/10/2005].

Poudel K. 2003. Course of disorder. Nepalnews.com, 22 (41), April 24-May 1 [Online] Available from: www.nepalnews.com.np/contents/englishweekly/ spotlight/2003/apr/apr25/coverstory.htm - 40k [Accessed: 08/09/2005].

Ross J. 2005. Strikes on vital ferry links threaten key Easter trade, The Scotsman, 15 March [Online] Available from: http/l:www.thescotsman.scotsman.com/index.cfm?id=280592005 - 47k - 12 Oct 2005 [Accessed: 09/09/2005]. 
Sauer RL \& Voelker KE. 1993. Labor relations: structure and process. $2^{\text {nd }}$ ed. New York: Macmillan.

The Namibian. 2005. Crippling SAA strike may end soon. The Marketplace, Thursday, 28 July [Online] Available from: http://www.namibian.com.na/2005/July/marketplace/05C9059C5B.html [Accessed: 04/10/2005].

Toness BV. 2005. Early travel smooth in first day of Northwest mechanic strike, 20 August [Online] Available from: www.news.minnesota.publicradio.org/ features/2005/08/19_ap_nwastrikeday1/ - 61k [Accessed: 09/09/2005].

Turnbull P, Blyton P \& Harvey G. 2004. Management-labour partnership in the European civil aviation industry. European Journal of Industrial Relations, 10(3):287-307.

Venter R. (ed.). 2003. Labour relations in South Africa. Rev. ed. Cape Town: Oxford South Africa.

Wadula P. 2005. Cometh the man, cometh the hour. Enterprise Magazine, 10 August:8.

Wolk M. 2005. Northwest strike seen as a watershed, August 24 [Online] Available from: www.msnbc.msn.com/id/9068558/ - 56k - [Accessed: 09/09/2005]. 